\title{
ANTENNAL MALFORMATIONS IN LIGHT OCELLI DRONES OF Apis mellifera (HYMENOPTERA, APIDAE)
}

\author{
CHAUD-NETTO, J. \\ Departamento de Biologia, IBRC, Universidade Estadual Paulista, CEP 13506-900, Rio Claro, SP, Brazil \\ Correspondence to: José Chaud-Netto, Departamento de Biologia, IBRC, Universidade Estadual Paulista, \\ Av. 24A, 1515, CEP 13506-900, Rio Claro, SP, Brazil, e-mail: depbio@rc.unesp.br \\ Received November 24, 1998 - Accepted February 18, 1999 - Distributed February 28, 2000
}

(With 1 figure)

\begin{abstract}
Malformed antennae of Apis mellifera light ocelli drones were drawn, dissected and mounted permanently on slides containing Canada balsam, in order to count the olfactory discs present in each segment, in comparison with the number of those structures in normal antennae of their brothers. Some drones presented morphological abnormalities in a single segment of the right or left antenna, but others had two or more malformed segments in a same antenna. Drones with malformations in both antennae were also observed. The $4^{\text {th }}$ and $5^{\text {th }}$ flagellum segments were the most frequently affected. In a low number of cases the frequency of olfactory discs in malformed segments did not differ from that one recorded for normal segments. However, in most cases studied, the antennal malformations brought about a significant reduction in the number of olfactory discs from malformed segments.
\end{abstract}

Key words: Apidae, Apis mellifera, drones, antennal malformations, olfactory discs.

\section{RESUMO}

\section{Malformações antenais em zangões de Apis mellifera de ocelos claros (Hymenoptera, Apidae)}

Antenas com malformações diversas, extraídas de zangões de Apis mellifera de ocelos claros, foram desenhadas e dissecadas para a contagem de discos olfativos dos segmentos morfologicamente alterados, em comparação com as antenas normais de seus irmãos. Alguns zangões apresentaram anormalidades morfológicas em um dos segmentos da antena direita ou esquerda, mas outros possuíam dois ou mais segmentos alterados na mesma antena. Zangões com malformações em ambas as antenas também foram observados. Os segmentos 4 e 5 do flagelo foram os mais freqüentemente afetados. Em um menor número de casos, a freqüência de discos olfativos nos segmentos malformados não diferiu significativamente em relação à observada nos segmentos normais. Contudo, na maioria dos casos estudados, as malformações antenais ocasionaram uma significativa redução no número de discos olfativos dos segmentos malformados.

Palavras-chave: Apidae, Apis mellifera, zangões, malformações antenais, discos olfativos.

\section{INTRODUCTION}

Frisch $(1919,1921)$ trained honeybees (Apis mellifera) to find a particular scent, which was initially associated with the liquid food they were collecting in an artificial feeder. After a great number of visits to the feeder he excised the eight distal segments of the antenna flagellum of each bee, and observed that they lost the ability to collect food. But, he also observed that the bees still presented some ability to find the odor they had been trained for, when three quarters or less of one 
antennal segment were maintained. These observations were also confirmed by Frings (1944) and Ribbands (1955) in independent experiments.

The antennae of bees are very complex organs which contain a great number of sensory structures classified in six groups of sensilla: placodea, trichodea, basiconica, ampullacea, coeloconica and campaniformia (Schenk, 1903). The sensilla placodea are transparent oval structures, whose outer smooth surface generally develops almost at the level of the antennal cuticle surface. A great number of these structures were found in the eight distal segments of each antenna (Richards, 1952; Slifer \& Sehkon, 1960), and it was thoughout that these sensilla may be involved in olfaction, a supposition confirmed in ulterior studies based on electro-physiology (Kaissling \& Renner, 1968; Schneider \& Steinbrecht, 1968).

The antennal structures of Apis mellifera has been studied by many researchers, and these investigations were carried out using both light and electronic microscopy (revision in Moraes, 1988). The number of antennal sensilla placodea, also called olfactory discs, in queens, drones and workers of A. mellifera was determined by many authors (Snodgrass, 1956; Esslen \& Kaissling, 1976; Stort, 1975; Stort \& Malaspina, 1980; Stort \& Chaud-Netto, 1980; Stort \& Barelli, 1981; Moraes, 1988). Nevertheless, little information about the frequency of olfactory discs in mutant honeybees is available. This paper deals with the number of sensilla placodea in light ocelli (by ${ }^{\mathrm{oc}}$ ) drones of Africanized honeybees with antennal malformations.

\section{MATERIAL AND METHODS}

Light ocelli drones of Apis mellifera (by ${ }^{\circ}$ genotype) with antennal malformations and drones with normal antennae were used in this research. Newly emerged drones of light ocelli phenotype have eyes and ocelli dark rose, whereas the wild drones have black eyes and ocelli (Chaud-Netto, 1977). All drones were descendent from a heterozygous queen allowed to fly and mate naturally in a mating area at the Campus of Rio Claro. Samples of light ocelli drones with malformed and normall antennae, were collected and fixed in Dietrich for at least 24 hours, and next transferred to $70 \%$ alcohol. Drawings for morphological observations of the antennae with one or more malformations were made using a camera lucida mounted on a Zeiss stereomicroscope. The method described by Stort \& Soares (1978) was used to count the number of olfactory discs in the antennae: each flagelum segment was first separated from the antenna and opened in the region opposite the frontal one, where no olfactory structures are present. Each segment was then spread on a slide containing Canada balsam, and pressed with a coverslip. With this technique the remaining tissue (nonchytinous) present inside the segment and obstructing the olfactory discs mixed with the balsam. Then the coverslip was removed and the segment rapidly treated with a xylol bath which removed the balsam and also the tissue fragments, leaving the segment completely clean. Each segment was then definitively mounted with balsam under the coverslip. The slides were examined in a common light microscope (320X magnification) in order to count the olfactory discs present in each segment. The countings were made with an optical reticle. The nonparametric U proof of MannWhitney (Siegel, 1979) was applied to the data obtained in this research in order to verify if there was any significant difference between light ocelli drones with antennal malformations and drones with normal antennae, in relation to the number of olfactory discs.

\section{RESULTS AND DISCUSSION}

Table 1 shows the mean numbers of olfactory discs in antennal segments of drones with normal antennae and drones with antennal malformations. The values obtained in the nonparametric $U$ proof of Mann-Whitney applied in order to compare the number of olfactory discs in both types of drones are also presented in the same table. It can be seen that, in all cases studied, the mean number of olfactory discs was smaller in malformed segments than in normal ones.

Drawings of the more frequent malformations observed in light ocelli drones are showed in Fig. 1. The arrows indicate only a part of the abnormal segments studied in this research. Some of the malformations are not indicate in that figure because no countings were made in those segments. 


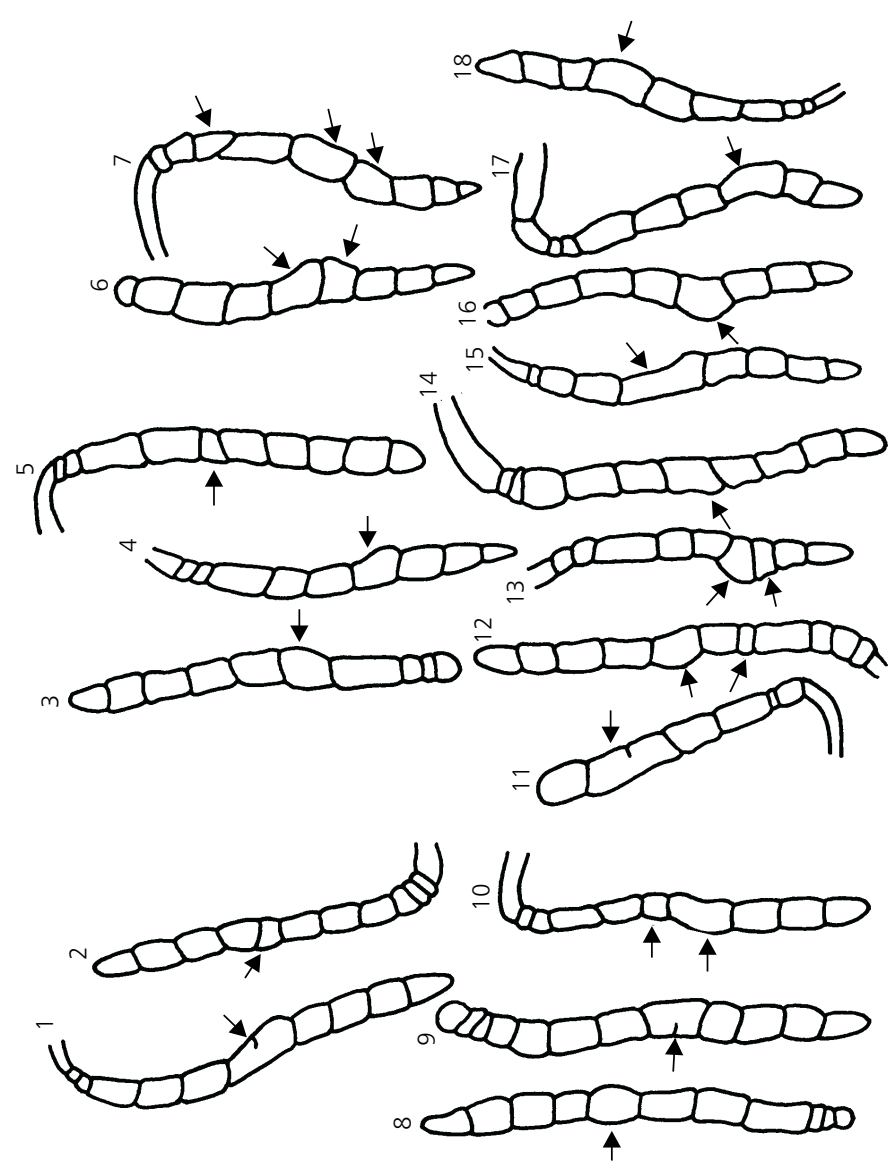

Fig. 1 - Antennal malformations found in Africanized honeybee drones of genotype by ${ }^{\text {oc }}$. The arrows indicate some of the abnormal segments used for countings of olfactory discs.

It can be seen that in some cases, the morphological abnormalities observed attained only a segment of the right or left antenna (Fig. 1, antennae 2, 3, 4, 5, 8, 14, 17 and 18). Nevertheless, in other cases, a same antenna presented two or more malformed segments (Fig. 1 antennae 6, 7, 10,12 and 13). Drones with malformations in both antennae were also recorded (Fig. 1 antennae 19, 2-10, 4-13, 6-16, 7-17). This fact was observed in the drones $1,3,4,8,9,10,14$ and 15 , which presented malformations in the antennal segments 4 and 5 of both antennae, and also in the drones $4,8,9,14$ and 15 which had morphological alterations in the segments 3,4 and 5 of both antennae. In a few cases the antennal morphologic alterations were only superficial, that is, there was no alteration in the number of olfactory discs in the segments considered (antennae 1, 9 and 11). In other cases, the number of segments present was smaller in relation to the observed in normal antennae (antennae 6, 7 and 11, for example).

The segments 4 and 5 were the most frequently affected (Table 1). Seven light ocelli drones presented antennal malformations in segments 5 and 6 simultaneously. So, in order to facilitate the countings of the olfactory discs and also the statistical analysis, these segments were computated together in those cases.

It was observed that, in most cases, the morphological alterations produced a significant reduction in the number of olfactory discs in the antennae of light ocelli drones. 
TABLE 1

Number of olfactory discs $(x \pm S D)$ in normal antennae and in malformed antennae of light ocelli drones of Apis mellifera, and values obtained in the nonparametric $U$ proof of Mann-Whitney.

\begin{tabular}{|l|c|c|c|}
\hline Antennal segments studied & $\begin{array}{c}\text { Drones with normal } \\
\text { antennae }\end{array}$ & $\begin{array}{c}\text { Drones with malformed } \\
\text { antennae }\end{array}$ & Value of U \\
\hline Segment 3 $(\mathrm{n}=7)$ & $607.0 \pm 94.3$ & $504.1 \pm 114.2$ & $13^{* *}$ \\
\hline Segment 4 $(\mathrm{n}=16)$ & $583.2 \pm 90.1$ & $424.5 \pm 152.4$ & $45^{*}$ \\
\hline Segment 5 $(\mathrm{n}=11)$ & $558.7 \pm 111.2$ & $376.3 \pm 112.5$ & $15^{*}$ \\
\hline Segments 5 $+6(\mathrm{n}=7)$ & $1352.7 \pm 89.6$ & $585.7 \pm 149.4$ & $0^{* *}$ \\
\hline
\end{tabular}

* Significant at $5 \%$ level.

** Significant at $1 \%$ level.

Nevertheless, it can also be noted that the number of olfactory discs in a few malformed segments was apparently equal in relation to the normal ones, and in some cases it was even greater. This fact was recorded for the drones 3, 6, 9, 11 and 12 (segment 4), 1 and 8 (segment 5), and drones 4, 9 and 14 (segment 3).

Vogel (1921) found 6,000 olfactory discs in each antenna of honeybee workers, and this mean value has been mentioned by many authors. However, Kuwabara \& Takeda (1956) recorded about 3,000 of these structures per antenna, and Dostal (1958) observed 2,888 ones. It is possible that the value related by Vogel was the whole number of olfactory discs recorded in both antennae. The results obtained by Snodgrass (1956) are similar to those of Dostal.

Stort (1979) made a comparative study between Africanized honeybee workers and Italian ones (Apis mellifera ligustica) and estimated the number of olfactory discs from $3^{\text {th }}$ to $10^{\text {th }}$ flagellum segments. The statistical analysis indicated significant differences between the two types of workers in relation to those structures, in all segments, except the segments 5 and 10 . Stort also compaired the number of olfactory discs and sensory hairs with variables of workers defensive behavior and concluded that the increasement in those structures makes the Africanized honeybee workers more sensitive for detecting and attacking the enemy.

Stort \& Chaud-Netto (1980) counted the olfactory discs of the $4^{\text {th }}$ antennal segment of Africanized haploid and diploid drones and verified that the last ones had a smaller number of these structures. Stort \& Malaspina (1980) estimated the number of sensilla placodea of the same segment in Africanized and in Italian honeybee drones, and concluded that probably there is no difference between these two types of males in relation to their capacity to detect the queen pheromone (9oxo-trans-2-decenoic acid) during the nuptial flight.

The results of the present research are very similar to those obtained by Jurgensen \& ChaudNetto (1983). These authors studied different antennal malformations in wild drones of Africanized honeybees, and observed that the segment 5 was the most frequently affected. They found that the number of olfactory discs in drones with malformations in that segment $(\mathrm{x}=481,8 \pm$ 219.4) was smaller in relation to the value recorded in drones with normal antennae $(\mathrm{x}=584.2 \pm 93.3)$. A similar result was obtained for segments $5+6$ analysed simultaneously in malformed males $(\mathrm{x}=$ $585.6 \pm 163.9)$ and in normal ones $(\mathrm{x}=1279.0 \pm$ $74.2)$, and also for segments $3(\mathrm{x}=556.5 \pm 31.8$, against $x=674.0 \pm 145.6), 4(x=557.5 \pm 98.3$, against $\mathrm{x}=609.0 \pm 29.7)$ and $6(\mathrm{x}=435,6 \pm 146.4$, against $x=563.0 \pm 89.7)$. In most cases considered by those authors, the morphologic alterations detected brought about internal changes in the antennae, almost always with reduction on the number of olfactory structures in malformed segments. These segments, in most cases, presented less sensilla placodea in relation to the antennal segments of normal drones, as was also observed in the present study. This fact suggest that males with malformed antennae may have smaller olfactory sensitivity in relation to the drones with normal antennae. It would be interesting to test this supposition by using experiments of electrophysiology. 
Acknowledgment - Research supported by CNPq, Proccess 300 703-81.

\section{REFERENCES}

CHAUD-NETTO, J., 1977, Ocelos claros (oc): a new mutation in Apis mellifera adansonii. Ciên. e Cult., 29(3): 316-318.

DOSTAL, B., 1958, Riechfähigkeit und zahl der riechsinneselemente bei der honigbiene. Z. Vgl. Physiol., 41: 179-203.

ESSLEN, J. \& KAISSLING, K. E., 1976, Zahl und Verteilung antennaler sensillen bei der Honigbiene (Apis mellifera L.). Zoomorphologie, 83: 227-251.

FRINGS, H., 1944, The loci of olfactory end-organs in the honeybee, Apis mellifera L. J. Exp. Zool., 97: 123-134.

FRISCH, K.V., 1919, Uber den geruchssinn der bienen und seine blutenbiologische bedentung. Zool. lahrb. Abt. Allgem. Zool. Physiol. Tiere, 37: 1-238.

FRISCH, K. V., 1921, Uber densitz der geruchsines bei insecten. Zool. lahrb. All. Zool. Physiol. Tiere, 38: 1-68.

JURGENSEN, A. C. \& CHAUD-NETTO, J., 1983 , Malformações antenares em zangões haplóides de Apis mellifera com conseqüente alteração no número de discos olfativos. In: $3^{\text {o }}$ Encontro de Geneticistas Paulistas, Jaboticabal/SP. Anais. Universidade Estadual Paulista, Jaboticabal.

KAISSLING, K. E. \& RENNER, M., 1968, Antennale rezeptoren für queen substance und sterzelduft bei der Honigbiene. Z. Vgl. Physiol., 59: 357-361.

KUWABARA, M. \& TAKEDA K., 1956, On the hygroreceptor of the honey bee Apis mellifera. Physiol. Ecol., 7: 1-6.

MORAES, M. M. B., 1988, Estudo morfológico e genético das antenas de abelhas da família Apidae (Hymenoptera, Apoidea). Tese de Doutorado, Universidade Estadual Paulista, Instituto de Biociências, Rio Claro, 203p.

RIBBANDS, C. R., 1955, The scent perception of the honeybee. Proc. Roy Soc. London B., 143: 367-379.

RICHARDS, A. G., 1952, Studies on arthropod cuticle. VIII. The antennal cuticle of honeybees, with particular reference to the sense plates. Biol. Bull., 103(2): 201-225.
SCHENK, O., 1903, Die antennalen hautsinnesorgane ciniger Lepidopteren und Hymenopteren mit berchsicktigung der sexuellen unterschide. Zool. Ialbiv., 17: 573-618.

SCHNEIDER, D. \& STEINBRECHT, R. A., 1968, Checklist of insect olfactory sensilla. Symp. Zool. Soc. London, 23: $279-297$.

SIEGEL, S., 1979, Estatística não paramétrica - Para as Ciências do Comportamento. Editora McGraw Hill do Brasil Ltda., São Paulo, 350p.

SLIFER, E. H. \& SEHKON, S. S., 1960, The fine structure of the plate organs on the antenna of the honey bee, Apis mellifera Linnaeus. Exp. Cell Res., 19: 410-414.

SNODGRASS, R. E., 1956, Anatomy of the honey bee. Comstock Publishing Associates, New York, 334p.

STORT, A. C., 1975, Genetic study of the aggressiveness of two subspecies of Apis mellifera in Brazil. II. Time at which the first sting reached the leather ball. J. Apic. Res., 14: 111-175.

STORT, A. C., 1979, Estudo genético de caracteres morfológicos e suas relações com o comportamento de defesa de abelhas do gênero Apis. Tese de LivreDocência, Universidade Estadual Paulista, Instituto de Biociências, Rio Claro, 179p.

STORT, A. C. \& BARELLI, N., 1981, Genetic study of olfactory structures in the antennae of two Apis mellifera subespecies. J. Kansas Entomol. Soc., 54(2): 352-358.

STORT, A. C. \& CHAUD-NETTO, J., 1980, Estruturas sensoriais e atividade de vôo em abelhas africanizadas (Apis mellifera adansonii). Rev. Brasil. Biol., 40(4): 717720.

STORT, A. C. \& MALASPINA, O., 1980, Comparação do número de estruturas sensoriais em machos de duas subespécies de Apis mellifera. Dusenia, 12(2): 51-56.

STORT, A. C. \& SOARES, A. E. E., 1978, Estudo de mosaicismo em antenas de Apis mellifera. Ciên. e Cult., 32(11): 1552-1554

VOGEL, R., 1921, Zue kenntnis der geruchsorgane der wespen und bienen. Zool. Ang., 53: 20-28. 